Contemporary Literature and Film 


\title{
Houses, Vases, Bicycles and Rocking Horses: 'Aryanised' Objects in the Documentaries Die Akte Joel and Mariannes Heimkehr*
}

\author{
By Judith KeILbach \\ j.keilbach@uu.nl
}

Film is a medium that makes things visible - and it does so in two ways: on the one hand the camera records the visual qualities of objects and on the other the pictures on the cinema or TV screen attract the attention of the viewer, inviting a closer inspection of the objects and persons depicted. In this process not only are objects visualised but emotions, too, are represented. Being able to make these two elements visible, film, as a medium, seems to be eminently suited to depict the connection between objects and emotions. It is therefore not surprising that many feature films imbue objects with an emotional charge and, equally, that documentary films, too, may emphasize the connections between objects and emotions.

This essay is concerned with the staging and presentation of objects in filmobjects that were taken away from their Jewish owners by way of 'Aryanisation'. Two documentaries in particular may give us answers to questions relating to the connection between objects and emotions: Die Akte foel (Beate Thalberg, Austria 2001) and Mariannes Heimkehr (Gert Monheim and Stefan Röttger, Germany 2003). Both show the processes involved in the expropriation and subsequent re-use of Jewish property by means of concrete examples, for example by depicting the fate of individual families. In contrast to the more abstract and analytical representations of Aryanisation such as Menschliches Versagen (Michael Verhoeven, Germany 2008) one would expect the films under discussion here, since they focus on individual families, to produce in their viewers a heightening of emotions as is also the case in other memory films. ${ }^{1}$ It is interesting to note, however, that both

\footnotetext{
*This article was translated from the German by Gabriele Rahaman.

${ }^{1}$ Apart from the many television documentaries that deal with Holocaust survivors or other contemporary witnesses, which present their memories as emotionally overpowering, there are also films that are concerened with the processes of remembering such as Shoah (Claude Lanzmann, France 1976-1985), Mendel Schainfelds zweite Reise nach Deutschland (Hans-Dieter Grabe, Germany 1971) or Im toten Winkel (André Heller and Othmar Schmiederer, Austria 2002). For theoretical discussions of traumatic memories and their representation in television or film documentaries cf. Shoshana Felman and Dori Laub, Testimony. Crises of Witnessing in Literature, Psychoanalysis, and History, New York-London 1992; James E. Young, Writing and Rewriting the Holocaust. Narrative and the Consequences of Interpretation, Bloomington
} 
these films refrain from emotionally charging the rescued or returned objects they are concerned with: these objects are not shown to refer back nostalgically to the past, or to exhibit traces of previous generations or to tell stories of the past. This restraint is a filmic strategy of mise-en-scène by using which Die Akte foel and Mariannes Heimkehr underline certain propositions and theses. How these two films present the topic of Aryanisation and what kind of strategies they use to, paradoxically, express visibly something that has been lost, in this instance the loss of property, will be the task of this enquiry. This analysis is preceded by a theoretical frameworking in order to demonstrate the potentiality of (lost) objects in the medium of film.

The special affinity between film and material phenomena has already been extensively discussed in classic film theory. Béla Balázs, for instance, pointed out that film lends a different kind of meaning to visible objects because any difference of degree between persons and objects is minimised by pictorial representation. ${ }^{2}$ André Bazin, however, maintained that photographic media have "the power to lay bare the realities" 3 because they record objects mechanically, "without the creative intervention of man". And Siegfried Kracauer even spoke of the "redemption of physical reality" to which film, in his opinion, contributes because of its ability to record the visible world.

While the concepts of Kracauer and Bazin are often discussed with respect to their different concepts of reality I would like, in this instance, to concentrate on the status of objects with regard to these theories. All three of these authors presume albeit for different reasons - that objects, before photography and film made it possible to (again) perceive and experience their object-ness [Objekthaftigkeit], were "degraded and diminished", 6 "covered" by preconceptions of "spiritual dust and grime", or stripped of their qualities. ${ }^{8}$ According to Balázs the camera "enhances the object's vitality and significance" ${ }^{9}$ and is able, as Bazin observes with respect to himself, "to present it ... to my attention and consequently to my love". ${ }^{10}$ Kracauer even speaks of incorporation: "In experiencing an object, we not only broaden our knowledge of its diverse qualities but in a manner of speaking incorporate it into us so that we grasp its being and its dynamics from within." ${ }^{11}$

1988, p. $57 f f$; Lawrence L. Langer, Admitting the Holocaust. Collected Essays, New York, Oxford 1995; Judith Keilbach, Geschichtsbilder und Zeitzeugen. Zur Darstellung des Nationalsozialismus im bundesdeutschen Fernsehen, Münster 2008.

${ }^{2}$ Béla Balázs, Early Film Theory: Visible Man and The Spirit of Film, New York 2010, p. 23. For the original version, see idem, Der sichtbare Mensch oder die Kultur des Films, Frankfurt 2001 (1924).

${ }^{3}$ André Bazin, 'The Ontology of the Photographic Image', in What is Cinema?, vol. I, Berkeley and Los Angeles-London 1967, p. 15.

${ }^{4}$ Ibid., p. 13.

${ }^{5}$ Siegfried Kracauer, Theory of Film: The Redemption of Physical Reality, London, New York 1960.

${ }^{6}$ Balázs, p. 23.

${ }^{7}$ Bazin, p. 15.

${ }^{8}$ Kracauer, p. $296 \mathrm{ff}$.

${ }^{9}$ Balázs, p. 23.

${ }^{10}$ Bazin, p. 15.

${ }^{11}$ Kracauer, p. 297. 
Since film has the ability to accentuate the significance of objects it would be reasonable to expect that Die Akte Foel and Mariannes Heimkehr would take advantage of this potential. This expectation is based partly on the observation that in present-day feature films, in which the materiality and the sensual quality of objects is stressed, the objects themselves receive loving attention. Documentary films, too, may generate this in order to make clear the significance or memory value of objects. In a short scene at the end of Menschliches Versagen, for instance, an image of a suitcase which, through being staged in a certain way, obtains an auratic charge. In this scene Christiane Picard talks of how, to her surprise, a suitcase which had belonged to a distant relation of her mother, had turned up again. While she is remembering the scene when the suitcase was first opened, the film shows a re-enactment of this first encounter, whereby the framing and lighting of the object emphasise its vitality and significance. And when Christiane Picard is talking about the sensual impression ("sinnlicher Eindruck") she experienced when she lifted the black cover and how the scent emanating from the suitcase pervaded her senses, the film makes it clear - through the rustling of the black cloth, the clicking of the locks and the slow opening of the case - that this is not only an experience which relates to the sensual qualities of the object but also an experience that makes it possible to grasp its being and its dynamics from within. The suitcase is thus enhanced with a certain aura by filmic methods which "in this sense is a kind of memory of the world experienced through objects and the traces left on them of practice and use." ${ }^{12}$

The expectation that in films addressing the topic of Aryanisation significant objects should be made visible is partly also guided by theory since many authors have stressed the connection between photographic images and memory. This special relationship is based not least on the indexical quality of photographs. In semiotic terms a photograph is a "sign which refers to the Object that it denotes by virtue of being really affected by that Object"13 It is assumed that the objects in question have inscribed themselves into a light-sensitive surface and have - "after the fashion of a fingerprint"14 - left a trace. As Roland Barthes points out this presupposes the presence of the pictured object "which has been placed before the lens, without which there would be no photograph"."

This knowledge about the presence of the depicted objects is made productive in films that deal with memory (Erinnerungsfilme) on two levels. Firstly, the loss of objects can (paradoxically) be made visible by showing photographs of lost objects which had still been in one's possession at the time the picture was taken; secondly, as was already demonstrated in the film Menschliches Versagen, the aura surrounding

\footnotetext{
${ }^{12}$ Damian Stutton, Photography, Cinema, Memory: The Cristal Image of Time, Minneapolis 2009, p.86.

${ }^{13}$ Charles Sanders Peirce, A Syllabus of Certain Topics of Logic', in The Essential Peirce: Selected Philosophical Writings, vol. II (1893-1913), Bloomington 1998, pp. 258-324, 291.

${ }^{14}$ Bazin, p. 15.

${ }^{15}$ Roland Barthes, Camera Lucida: Reflections on Photography, New York 1981, p. 76.
} 
objects which have been rescued or found, and which are charged with memories and emotions, can be emphasised and made accessible to the viewer. ${ }^{16}$ Both these procedures deal with the past nostalgically. ${ }^{17}$

It will become evident that Die Akte Foel und Mariannes Heimkehr do not make use of auratic charging when dealing with lost objects. This may have something to do with the individual protagonists whose family history is used to describe the Aryanisation of Jewish property and who - like Marianne Stern, for instance reject any feelings of nostalgia. Generational changes may also make a nostalgic attitude regarding (lost) objects more difficult, since grandchildren have no direct memory of these objects. But above all it is the main focus of interest of these two films which goes against the staging of objects in this way. Neither Die Akte foel nor Mariannes Heimkehr deals primarily with the experience of loss. Using individual examples, both films rather take a critical stance towards juridical, institutional, economic or societal aspects of Aryanisation and restitution, while at the same time also focusing on those Germans who profited from Aryanisation.

In the following I aim to show which methods Die Akte Foel and Mariannes Heimkehr use to represent the loss of property. It can already be said at this point that neither of these two films develops particularly original filmic strategies to do so. That would be too much to expect anyway since these two films endeavour to throw light on events, and to document them in a journalistic way. It is exactly because both films are rather conventional in the techniques they employ that they are most suitable for exploring how aryanised property is dealt with in film.

\section{DIE AKTE JOEL}

The documentary film Die Akte Foel (2001) was produced for Austrian Television (ORF) and directed by Beate Thalberg. It received, among other awards, the Rose d'Or, an international television prize. There is a 45-minute version produced for television and an international version, fifteen minutes longer with English subtitles and voice-over commentary, which was shown at numerous festivals and on which the following analysis is based.

Die Akte foel tells the story of Josef Neckermann, and Karl Amson Joel, a Jewish businessman who founded a mail-order textile business in Nuremberg at the end of the 1920s. In 1934 the antisemitic weekly paper Der Stürmer launched a campaign against him and Joel was forced to leave and move his flourishing business to Berlin. Finally, in 1938, under increasing pressure of Aryanisation (the company was boycotted by 'Aryan' suppliers, its parcels were labelled as 'Jewish goods') Joel

\footnotetext{
${ }^{16}$ Walter Benjamin, who welcomed the disappearance of the concept of 'aura' in the age of mechanical reproduction pointed out that "the film responds to the shriveling of the aura", for instance through "the cult of movie stars". See Walter Benjamin, "The Work of Art in the Age of Mechanical Reproduction', in Illuminations, New York 1968, pp. 217-251, 231. The present-day emphasis on the sensual qualities of objects could be described as an additional cinematic strategy of auratic charging.

${ }^{17}$ Regarding objects being 'nostalgically charged' see Ben Furnish, Nostalgia in fewish-American Theatre and Film, 1979-2004, New York 2005, p. 5.
} 

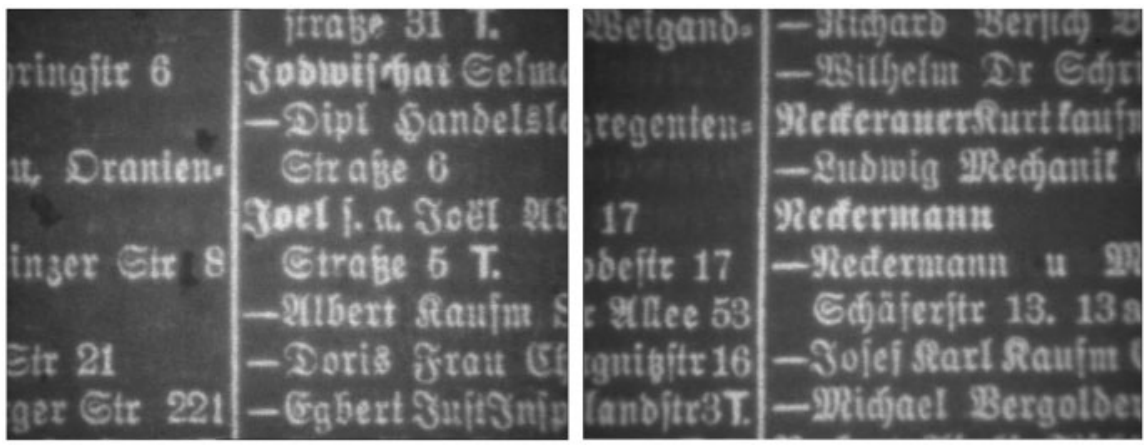

Berlin Telephone Directory showing change of entry from Joel to Neckerman, by courtesy of Die Akte Foel (Beate Thalberg, Austria 2001).

sold his business for much less than it was worth to the ambitious entrepreneurJosef Neckermann. Subtitled 'A Story of Two Families', this film recounts the flight of the Joel family via Switzerland and Cuba to the USA; Josef Neckermann's business deals with regard to the production of clothing for the Wehrmacht and for forced labourers; the Joels' difficult early years in New York where they created a business from scratch; and the rise of the Neckermann mail-order business, generally considered a show-piece of the German economic miracle. The legal case dealing with restitution which Karl Joel brought against Neckermann after the war is mentioned only briefly. Neckermann's criminal gambit to trick Joel out of the already reduced sale price is mentioned only as an aside and the fact that Joel, after several years of litigation, only received compensation to the value of the reduced sale price is only implied and is never discussed explicitly. The film shows an arranged meeting of the Joel and Neckermann grandchildren who, however, do not seem to have much to say to each other: while Billy and Alexander Joel expect Markus, Julia and Lukas Neckermann to deal critically with the role their grandfather played, the Neckermann grandchildren are convinced that their grandfather was innocent and even talk about 'resistance' on his part. Julia Neckermann, for instance, replies to Billy Joel's remark that there were indeed some Germans "who did fight against bad things, who did good things" by characterising her grandfather as a resistance fighter - a reinterpretation quite typical for the grandchildren's generation. "My grandfather's way of fighting against the regime" she says "was to help the people have jobs, help the people have uniforms for the winter" - a statement which the film, however, challenges by placing it after a sequence showing forced labourers in Theresienstadt whom Neckerman used to produce garments for his business.

${ }^{18}$ Cf. Harald Welzer, Sabine Moller, Karoline Tschuggnall, 'Opa war kein Nazi'. Nationalsozialismus und Holocaust im Familiengedächtnis, Frankfurt am Main 2002. 
Apart from the scenes involving the grandchildren, which are inserted into the narrative flow and represent the way the past is dealt with, the film follows the chronology of events. By running the two stories in parallel it is clear right from the start that the protagonists' life trajectories are inextricably linked - this is frequently also made explicit when montage and voice-over accentuate contrasts and differences. The film, for instance, contrasts the upper middle-class background of Josef Neckermann with the difficult beginnings of Karl Joel's mail-order textile business (parcels were packed at home and taken to the post office by cart). Formal elements of the film include interviews with family members (apart from the grandchildren, the sons Helmuth (Howard) Joel and Johannes Neckermann also have their say) and with former members of staff, as well as historical footage. These images are mainly used to illustrate the voice-over commentary. For example, when Joel's mail-order business is sold or when the Neckermanns move into the Joel family mansion, this is visually put across by showing the change in letter-headings or the change of addresses in the Berlin telephone directory.

However, every now and then the film uses such footage to make a visual argument that is independent of what is said in the commentary.

Die Akte Foel reconstructs the history of one instance of Aryanisation which, not least because of the specific constellations of the personal histories and the prominence of the protagonists involved, is of special interest to the viewer. However, the film also has a number of weak points. Among these are the illustrative use of historical footage which not only weakens the intensity and referentiality of the photographic images but also undermines the status of the objects presented in the film. The images and film clips seem to have been selected in order to arrive at a general congruence between visual motif and commentary. When, for instance, it is mentioned that Neckermann was responsible for the provision of clothing to forced labourers, the film shows people in prisoner's garb as well as men carrying spades who jump off lorries and start to dig trenches under the supervision of Wehrmacht soldiers. And when Helmuth Joel talks of how members of his family and a neighbour were deported, the film shows people on platforms and in train carriages. On the one hand the use of such pictures as vague visual equivalents to the commentary on forced labour and deportations severs the connection between what the images depict and their meaning. For example, by illustrating the concept of forced labour mentioned in the commentary with a take of Orthodox Jews digging trenches, our attention is removed from the depicted situation. We no longer see Orthodox Jews digging trenches but forced labour. The image thus becomes an abstraction. ${ }^{19}$ On the other hand using images in this way frequently results in contradictions, especially when the context of how the image in question came about is well known. Since we know that the girl looking at us from inside the carriage while Helmuth Joel is talking about the deportation of his

\footnotetext{
${ }^{19}$ Regarding this transformation in the context of Holocaust images cf., for instance, Clément Chéroux, 'Du bon usage des image', in Mémoire des Camps. Photographies des camps de concentration et d'extermination nazi (1933-1999), ed. by Clément Chéroux, Paris 2001, pp. 11-21, 13.
} 
neighbour is not his neighbour but Settela Steinbach who was deported to Westerbork and later murdered in Birkenau, ${ }^{20}$ we feel that the photograph loses its validity (and the statements of the person interviewed lose their intensity). The uncertain status of historic images is simultaneously also transferred to the depicted objects. Ultimately one is not certain, for instance, whether the images used to depict Joel's car, house or company buildings are photographs of the objects in question or just some arbitrary generic images.

Beyond that, one can discern a lack of historical precision and a lack of clarity in the narration regarding transactions dealing with Aryanisation and restitution processes. In particular, the conciliatory ending of the film, when Markus Neckermann is presented as one of Billy Joel's biggest fans, thus suggesting a reconciliation of the two families even though their differences had been quite obvious in previous scenes, seems problematic. In other words, this final scene of Die Akte Foel appears to be too simplistic, especially in light of the complex nature of the history the film deals with - a complexity that emerged during the research for this film project which was originally planned as a portrait of the conductor Alexander Joel and his older half-brother, the pop-singer Billy Joel. ${ }^{21}$ By ending Die Akte foel with a closure that purports to resolve all contradictions, the medium's great potential to "render historical complexity" remains unused. ${ }^{22}$

\section{MARIANNES HEIMKEHR}

Mariannes Heimkehr is a documentary written and directed by Gert Monheim and Stefan Röttger about Marianne Stern (neé Winter), who was deported to the Riga ghetto in 1941. She returned to her home village of Hemmerden after the war where she had to struggle for years with neighbours and the local tax authority for the return of her property which had been auctioned off and distributed amongst her neighbours in the village. This 45-minute documentary was conceived as part of the WDR series die story, whose co-founder and director, the journalist Gert Monheim, is well known for his persistence and his thorough research. ${ }^{23}$ Mariannes Heimkehr was based on extensive research by the historian Wolfgang Dreßen who scrutinised the files of the tax authorities in Cologne at length for an exhibition on the Aryanisation of Jewish property. ${ }^{24}$ Dreßen frequently stresses in his book about the exhibition that the persons whose actions he uncovers are interchangeable

${ }^{20}$ Cf. Thomas Elsaesser, "Un train peut en cacher un autre". Geschichte, Gedächtnis und Medienöffentlichkeit', in Montage AV 11, 1, 2002, pp. 11-25, 23ff.

${ }^{21}$ 'Neckermann, nicht möglich', Daniel Fersch, in Die Tageszeitung (19 December 2001).

${ }^{22}$ Cf. Robert Rosenstone, Visions of the Past: The Challenge of Film to our Idea of History, Cambridge and London 1995, p. 38.

23 'Abschied eines Dickbrettbohrers' Reinhard Lüke, in Frankfurter Rundschau (29 June 2009).

${ }^{24}$ The exhibition Betrifft: "Aktion 3". Deutsche verwerten jüdische Nachbarn was first shown at the Stadtmuseum Düsseldorf (29 October 1998-10 January 1999) and then in several other German cities. The exhibition documents were also published in book form: Wolfgang Dreßen, Betrifft: "Aktion 3". Deutsche verwerten jüdische Nachbarn. Dokumente zur Arisierung, Berlin 1998. 
figures serving as examples who reflect the whole of society. ${ }^{25}$ Similarly, Mariannes Heimkehr does not aim to accuse individuals. The film focuses instead on the administration of aryanised property, on the legal obstacles encountered when reclaiming such property, and on the various relationships within the neighbourhood under scrutiny in this film.

As the film's subtitle Die füdin, der Beamte und das Dorf clearly implies, Mariannes Heimkehr does indeed deal with the Aryanisation of the Winter family property and the subsequent struggles to have it returned; the film depicts this as a conflict between Marianne Stern, the tax official Josef Krüppel, and the inhabitants of Hemmerden. After the deportation of Karl and Rosalie Winter, their daughters Herta and Marianne as well as Herta's husband Richard Schmitz, Krüppel was entrusted with the auctioning of the Winter family's household effects. He compiled a detailed list of these items to which, at a later stage, were added the purchasers' names and the prices obtained. In addition, Krüppel functioned as administrator of the Winter family home which had been transferred into state ownership after expropriation. The people of Hemmerden were surprised when Marianne, who was the only one of her family to survive the ghetto, forced labour and a death march, returned to the village. The people who were now renting the house did not hesitate to tell Marianne they had hoped "that none of you would come back, that's why we moved in". They even threatened to push her down the stairs, making comments such as "since she did not die in the concentration camp, she is going to die here".

The tax authority, which had diligently kept lists and receipts of Marianne's auctioned household effects, was responsible for dealing with her restitution claims. Once Marianne had obtained the auction records she visited her neighbours to enquire about the return of these objects. They regarded her request as an impertinence since they had after all acquired them 'legitimately', that is, they had paid for them. Some maintained that these objects had been farewell presents given to them by her mother. One such example was the village policeman who had taken the Winter family in 1941 from their home to be transported to the Riga ghetto and in whose flat Marianne, after her return, discovered a vase that had belonged to the Winter family.

In her attempts to regain these objects Marianne frequently had to deal with Josef Krüppel who, after the war's end, continued with his work as a tax official, dealing with the administration of the Winter family home. One day, when he went to the house to investigate some damage, Marianne saw that he was riding her dead brother-in-law's bicycle. "It's about time you returned that bicycle", she told Krüppel who proceeded to tell her that he had no obligation to do so. "Not according to the law", Marianne had to admit, "but morally speaking you do [have this obligation]". She threatened to spread the word "that a certain tax authority official from Grevenbroich was still riding a Jewish-owned bicycle [Judenrad]".

${ }^{25}$ See Dreßen, p. 130. 
Using this incident as an example - for which Marianne was severely reprimanded by the Oberfinanzpräsident (the highest ranking local tax official) - the film focuses on the juridical practices regarding restitution claims according to which the purchasers of auctioned goods had to be compensated first before the objects in question could be returned to the original owner. The film also makes clear how indignant the survivors felt when they realised that their neighbours had made a grab for their property in order to obtain a 'bargain' while they themselves were fighting for survival in ghettos and concentration camps. ${ }^{26}$ Having to prove racist persecution in order to be even considered eligible for restitution claims increased the survivors' feelings of outrage as the film makes abundantly clear: Marianne struggled to have herself recognised as a racially persecuted person by the court which at first rejected her claim since, as the presiding judge said, there were no documents to prove that she and her husband had indeed been incarcerated in a ghetto and subsequently in a concentration camp. After this comment Marianne shouted at the official so that all could hear: "May I tell you where we were? [...] All our relations died there [in Riga] in a skiing accident!"

Apart from the voice-over commentary there are also contributions from a number of villagers. They talk about events and about Krüppel, the tax official, and also about their memories of Marianne; this way the film gives rise to the impression that Marianne and Krüppel were fatefully connected. In the film we also hear Marianne tell her own life-story - recorded on tape before her death in 1998. But the film does not only present reminiscences: the filmmakers also confront some of the village residents with the auction lists which prove beyond doubt that their parents, too, had bought items from the household effects of the Winter family. That these interlocutors continue to utter negative opinions about Marianne despite these embarrassing revelations, shows how emotionally charged these events were and still are: "She made herself so unpopular that she no longer had any contact with the village until the day she died" says one of Marianne's fellow pupils, while another person justifies his rejection of Marianne by pointing out flaws in her character which reportedly had had a polarising effect from childhood onwards. The way things are said allows the viewer to sense how indignant Marianne and the village residents feel towards each other.

The historic picture footage used in Mariannes Heimkehr consists almost exclusively of photographs of the persons involved or the places described, such as the Winter family home. The documents relating to the events described - lists of property, auction lists, correspondence between Marianne and the tax authority are shown in close-up so that the viewer is able to read the main passages. In addition present-day views of the village are shown and the film also makes use of re-enactments: shots of a sewing machine or of bales of material being unfolded represent Karl Winter's bespoke tailoring business; pulled-out drawers containing

\footnotetext{
${ }^{26}$ In Mariannes Heimkehr it is not Marianne herself who describes the deportation, or life in the ghetto and in the concentration camp. This is done by Ilse Rübsteck who lived in the neighbouring village; speaking not only for herself, or Marianne, but for all victims she describes in detail how Jews were exposed continuously to death threats.
} 
sewing materials and furniture that has been turned over illustrate how the business was destroyed in the November pogrom of 1938. A scene depicting a man who grabs files from a desk and puts them into his briefcase, takes a coat off a coat stand and leaves the office with a cash box in his hand segues into a scene about the auctioning of the Winter family household effects by Krüppel. ${ }^{27}$

Mariannes Heimkehr is a film that leaves its viewers irritated. There are several reasons for this. On the one hand Marianne, the protagonist, does not correspond to the usual image of a Holocaust survivor as generally portrayed in films and television programmes. She is not the archetypal victim, marked by traumatic experiences, but a person who makes demands and takes her life into her own hands, using all means available to fight for her rights. On the other hand the story told by the film is disturbing as it raises fundamental questions regarding the legitimacy of property; the need for a sense of guilt and for what is right and wrong; and the (im) possibility of harmonious coexistence within society. Since the film refrains from offering us a conciliatory ending, these questions remain unresolved and therefore disquieting for the viewer.

In addition, Mariannes Heimkehr does not present any persons who seem instantly likeable. Marianne herself remains an ambivalent figure, partly because she is characterised through observations made by others, partly because of her way of speaking. The interviewees who show understanding for her actions discredit themselves when they break into Nazi song. Marianne's son remains uncommunicative and withdrawn. And, finally, it is disconcerting that Marianne herself does not appear although her voice can be heard. Because of this it is more difficult to assess her personality, especially since her emotions can only be deduced from the way she speaks. ${ }^{28}$ Her accent, originating from the lower Rhine area, is so strong that her statements have to be subtitled which adds to the viewer's uncertainty; it remains largely unclear whether her voice is marked by anger or by triumphal feelings when she remembers how successful she was when she demanded the return of her goods from her neighbours. In any case, her idiosyncratic way of describing things and events altogether thwarts any feelings of nostalgia, and the opacity of her emotions and intentions adds substantially to the effect that the situations depicted in the film are felt to become more and more unbearable.

\section{Objects}

Both Die Akte Foel and Mariannes Heimkehr deal with the loss of property, with the object-ness of the various lost objects being stressed in different ways and to different degrees. This has to do, not least, with the objects themselves which the

${ }^{27}$ Nearly identical images are used to visually underline the voice-over commentary stating that Josef Krüppel "continued with his job at the tax authority straight after the war, picking up work from where he had had to leave it a few months before".

${ }^{28}$ Regarding access in documentaries to the thoughts, emotions and actions of actual persons cf. Christine Brinckmann, 'Die Rolle der Empathie im Dokumentarfilm', in Matthias Brütsch et al. (ed.), Kinogefühle. Emotionalität und Film, Marburg 2005, pp. 333-360. 
films focus on. While Die Akte Foel concentrates on the Aryanisation of the Joel mailorder business, Mariannes Heimkehr focuses on the family home and the household goods of the Winter family. Such different objects require different forms of visualisation; while objects such as vases or bicycles or houses may easily be depicted by simply filming or photographing them, the representation of a business that employs staff, produces goods and delivers them to their customers is much more complicated. It was Bertolt Brecht who, in his critique of the medium of photography, observed that processes, networks and structures cannot be depicted: "A photograph of the Krupp or AEG factories tells us almost nothing about these institutions." Thus Brecht comes right to the point of the fallacy that "a 'simple representation of reality' says anything about reality., ${ }^{29}$

Die Akte foel manages to hint at the structural framework of the Joel mail-order business when it mentions the boycott by 'Aryan' suppliers or the attempted deterrence of customers by marking parcels as 'Jewish goods', but in essence the company symbolises Joel's enterpreneurial success and the fact that it ensures the economic basis of existence for the Joel family. Apart from the general difficulties in visually representing a company, it is above all this symbolic function which makes the company disappear as an object. Even the short insertion of historical and contemporay frontal views of the company building when the film is dealing with Joel's (and later Neckermann's) mail-order business does not contribute to its perception as a material object.

That the object status of things has a considerable effect on the way the story is told in the films and on the characterisation of the protagonists becomes apparent when one compares the two films' different ways of representing real property. In Die Akte foel not only the company building but also the home of the Joels is shown, for instance when the film mentions that the Neckermanns moved into the Joel family mansion. In Mariannes Heimkehr, however, the film deals with the family home of the Winters. Although the aryanised properties in both films are visualised in formally similar ways (both historical photographs and presentday film takes are used) the feelings they evoke are different in their intensity: Die Akte foel uses the Joel family mansion to suggest that Neckermann has simply taken over Joel's life, including his furniture and driver, while Mariannes Heimkehr defines the family home of the Winters as the centre and basis of their life and existence. Not only the whole family lives there, but the tailoring business Karl Winter had founded is also located there. After having been liberated, Marianne returns and takes possession of this home (she moves into a flat in her old family property, quarrels with neighbours and opens a small store in the space once occupied by her father's tailoring business) and when, in the film, her son Karl F. Stern is interviewed one cannot rule out that this interview is taking place in exactly the same house.

\footnotetext{
${ }^{29}$ Bertolt Brecht, 'Der Dreigroschenprozeß. Ein soziologisches Experiment' [1931], in Gesammelte Werke in 20 Bänden, vol. 18, Frankfurt am Main 1967, pp. 139-209, 161. Although Brecht here focuses on the reification of human relationships in capitalism, his remark is also valid with respect to the structural framework of business enterprises.
} 
In Mariannes Heimkehr the status of this house as an object is thus emphasized to a signficantly higher degree than in Die Akte foel. This is partly achieved by the fact that many of the events mentioned in the film are directly linked to the house (such as how the tenants reacted when Marianne returned, how Marianne demanded the return of her household effects or the occasion when Krüppel arrived by bike to inspect damage to the house, and so on). In addition, Mariannes Heimkehr suggests right from the start that these objects are emotionally charged, for instance when it says in the voice-over commentary: "When she attempts to enter her parental home she is not allowed to do so - other people are living there now". While this introduction (as well as the term Heimkehr (homecoming) used in the film's title) stresses the nostalgic notion of returning to one's childhood home, the film itself proceeds to show that Marianne's rootedness in Hemmerden has nothing to do with the closely-knit village community. Although the film does not explicitly state why Marianne never left this hate-filled environment, it nevertheless implies that it was the house that tied her to this place. The questions to what extent the real property value of the house ensured her economic survival or how much the parental property meant to her as an emotionally charged object that meant 'home' to her, remain unanswered. Because of this, the film manages to hold on to the ambivalent character of its protagonist, which in turn strengthens its basically anti-nostalgic stance.

That a house can be more than real property is shown most impressively by the documentary film Menschliches Versagen. ${ }^{30}$ This film contains a few scenes in which houses are visited and to which connections are made via memories. In one instance, Edgar Feuchtwanger is shown returning - after nearly seventy years - to the flat where he had lived to the age of fourteen. With Bea Green, his childhood friend who had been a frequent visitor at the Feuchtwangers, he walks through the apartment his parents once owned. They are both trying to remember where the various pieces of furniture were placed, where they had played together and where the grand piano stood which Edgar Feuchtwanger had played as a child.

The way he moves while walking through the apartment demonstrates that there is a deeply ingrained body-memory at work here, for instance when he positions himself on a particular spot in the room in order to show where exactly he was sitting when playing the piano. Doing so, he imitates the finger movements of a piano player, a gesture which he then expands, encompassing with a sweeping motion the wall opposite, indicating where the "very beautiful bookcase" had been in which his father, the publisher Ludwig Feuchtwanger, had kept "his beautiful old books". Apart from his gestures it is the contrast between Feuchtwanger's description of a study filled with bookshelves and the now bare office walls which tells us that there are memories connected to each nook and cranny of this place.

\footnotetext{
${ }^{30}$ The film traces the processes of Aryanisation by connecting the statements of numerous historians, archivists and those affected by Aryanisation. The result is a mixture of analytical description and personal histories.
} 


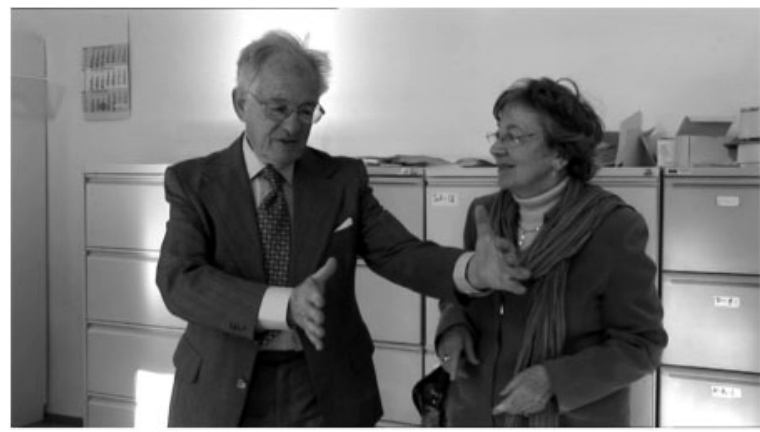

Edgar Feuchtwanger and Bea Green in Feuchtwanger's childhood home, by courtesy of Menschliches Versagen (Michael Verhoeven, Germany 2008).

This scene shows, as Siegfried Kracauer has pointed out in his Theory of Film, ${ }^{31}$ that there is such a thing as body-memory of objects. That neither Die Akte foel nor Mariannes Heimkehr emphasize this dimension is not least due to the fact that these films address different questions. They do not deal so much with the experience of loss as with the reconstruction of the gradual dispossession and the deprivation of rights that German Jews experienced, as well as with the critical examination of the various ways restitution was handled.

It is very interesting to note that both films refrain from visually representing any other objects that are part of the aryanised property. Since Die Akte foel deals mainly with the parallel stories of two families this is more noticeable in Mariannes Heimkehr with its focus on particular objects. However, in Mariannes Heimkehr the fact that much talked-about objects are not visualised leads to viewer irritation: neither the vase that Marianne takes from the flat of the village policeman nor the bicycle she asks Krüppel to return are shown in the film. But Mariannes Heimkehr makes up for this by substituting a number of objects in re-enacted scenes. The objects in these scenes function, as already mentioned, either as substitutes whose object-ness is stressed or as symbols that point to a different meaning which lies beyond the actual object.

In scenes involving the bicycle of Marianne's brother-in-law, for instance, we are not shown the original bicycle but a substitute. While the voice-over commentary introduces the story behind the bicycle, which is then continued by Marianne's voice on tape, the wheels and pedals of a bicycle are depicted. The way this scene is staged (close-ups, colouring) leaves us in no doubt that this is a different bicycle from the brother-in-law's bicycle on which Krüppel arrives at Marianne's place. This deliberate strategy of not presenting the original bicycle has a special effect in that it

\footnotetext{
${ }^{31}$ For discussions on the body functioning as memory storage and on memories being triggered by visits to significant locations cf. Aleida Assmann, Erinnerungsräume. Formen und Wandlungen des kulturellen Gedächtnisses, München 1999.
} 
strengthens the argument underpinning Mariannes Heimkehr: it prevents the object from being auratically charged. The dead brother-in-law never used this bicycle and has therefore left no traces attached to it. The film simply shows an object that is a means of transport, an object to which no particular memories are attached. ${ }^{32}$

The substituted bicyle adds to the visualisation of Marianne's tale but another prominent object, a rocking horse, serves merely as a tool to enhance the reenacted scene, that is to say it is really a fictitious object. When the voice-over commentary talks of Marianne's father's tailoring business the camera pans round to some shelves, tailoring dummies and sewing-tables and also a rocking horse to complete this nostalgic view.

Later, to illustrate the events of the Reichspogromnacht, the camera repeats the same movement but this time it moves through the devastated room finally showing us the rocking horse that has been knocked over. The rocking horse may be considered as a symbol of childhood and the commentary supports this association by not only mentioning the events of that night but by also by commenting that Marianne's "world has collapsed" around her, thus suggesting that this is the end of her childhood.

This stylistically exaggerated re-enactment (sepia tones, soft lighting) prevents the viewer from perceiving the rocking horse as an object that has actually been lost. Whether Marianne ever owned a rocking horse remains a completely open question. The film rather makes use of this toy in order to visually symbolise the abrupt and violent end to Marianne's childhood.

Because the scenes in Mariannes Heimkehr involving the bicycle and the rocking horse are staged in a rather overt and exaggerated manner, auratic charging of these objects is avoided. This also benefits the characterisation of the protagonists whose actions - when judged against the background of convential portrayals of Holocaust survivors - appear irritating. By portraying the bicycle as an article of daily use (rather than as an object to which memories cling) and the rocking horse as an object with symbolic value, the film suggests that Marianne's demands for the return of expropriated household objects are not motivated by nostalgia. Similarly, her actions do not seem to be dominated by feelings of mourning but rather by sentiments that are inherent in situations of fighting for the return of one's property, such as strong feelings of righteousness, anger and a sense of justice.

It remains a matter of speculation why original objects are not shown in Mariannes Heimkehr. Perhaps it was simply the case that these objects no longer existed after so many years. It is possible that the vase broke and the brother-in-law's bicycle was replaced by a new one. At the same time there might have been formal and aesthetic reasons for not using the original objects. Precisely because the objects shown are not imbued with an auratic charge, the film is able to focus on the structural processes of Aryanisation and restitution and on the network of

\footnotetext{
${ }^{32}$ As a sign the image of this bicycle, as well as the words that were noted down in the auction lists, refer back to the original object itself (cf. Peirce, pp. 258ff.) and it is this difference which makes it possible to emphasize that these objects are lost objects; following Derrida, their visualisation might therefore be described as a trace (cf. Derrida, Writing and Difference, London-New York 1978).
} 

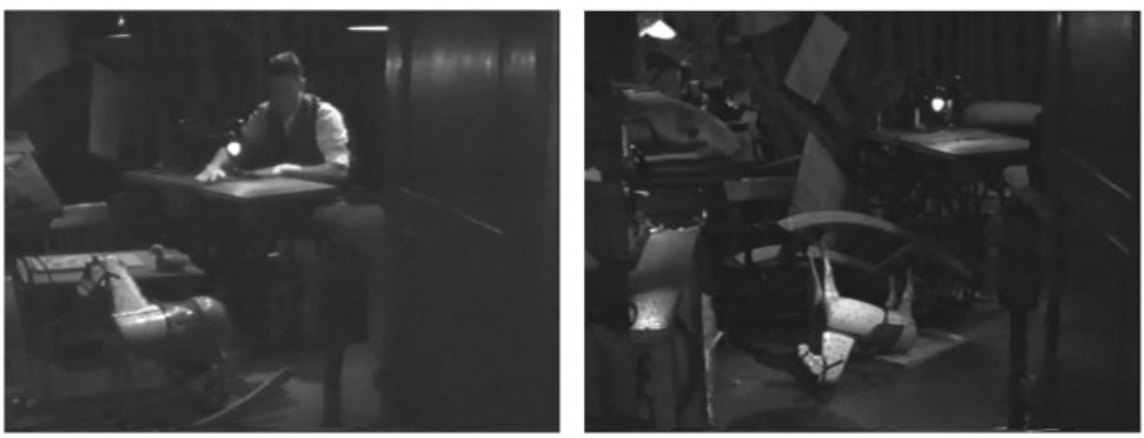

The Winter's tailoring workshop before and after the Reichspogromnacht, by courtesy of Mariannes Heimkehr (Gert Monheim \& Stefan Röttger, Germany 2003).

relationships within the village community. Beyond this, the missing objects could also be perceived as pointing to the many other lost objects which were not returned and which therefore could not be filmed. These assumptions aside, it is important, above all, to note the effects produced by employing the strategy of deliberately not showing the original objects. By doing so the film prevents the emergence of nostalgic feelings for these objects. This in turn makes Marianne's demands for the return of the aryanised objects appear as a fight based on fundamental principles, as a struggle against the morally unjust acts of expropriation her neighbours have committed. How much her actions were also influenced by emotional attachment to these objects does not play any role in Mariannes Heimkehr.

\section{Emotions}

Although neither Die Akte foel nor Mariannes Heimkehr presents objects to which personal memories or emotions have accrued, both films contain a number of scenes in which a link between objects and emotions is established. This is done, above all, via the medium of sound - in Mariannes Heimkehr the voice is of prime importance, ${ }^{33}$ while in Die Akte Foel it is music that plays the most significant role. In Mariannes Heimkehr, for instance, the way the story is narrated suggests quite clearly that the discovery of the vase in the house of the village policeman was an emotional moment: the policeman offered (perhaps prompted by feelings of shame or guilt) to return the vase and Marianne (possibly feeling enraged and contemptuous) removed the snowdrops that had been placed in the vase. In addition, the fact that the daughter of the policeman still remembers this event "as if it had been yesterday" seems to point to the emotional involvement of this person as well. The manner in which certain objects are talked about again suggests that strong emotions were involved here. Marianne's voice (on tape) also sounds

\footnotetext{
${ }^{33}$ Regarding the voice in film cf. Michel Chion, The Voice in Cinema, New York 1999.
} 
extremely enraged when she talks about Krüppel arriving on her brother-in-law's bicycle despite the passing of so many years. ${ }^{34}$

In Die Akte Foel, by contrast, music takes on an important function, creating an emotionally charged undertone which is of central significance, for instance, in the scene in which Helmuth Joel talks of his return to Nuremberg. Helmuth remembers how in 1945 - after having emigrated to the USA - he returned to Nuremberg as an American soldier and saw there a chimney which his father, before he had moved his company to Berlin, had used as an advertising space. "In the middle of the rubble stood that chimney with the name 'Joel' painted on it", he says. While his voice sounds sober, at times even slightly amused, the film evokes deep emotions by using music: the image of a chimney left standing in the rubble is accompanied by a few pathos-laden bars of Mahler's sixth symphony. This combination of music, image and description of the situation triggers overpowering emotions which on the surface seem connected to the object in question. That this object is a chimney seems to be - in the context of National Socialism - a particularly poignant irony of fate. But the emotions evoked here are much more diffuse than that. They are concerned with survival, rescue, loss and mourning which the film in this scene presents as a "dialectical image" as Walter Benjamin would have it. In a brief moment "what has been comes together in a flash with the [here and] now to form a constellation", ${ }^{35}$ whereby history to its fullest extent and in all its tragedy is "flashing up in the now of its recognizability". 36 The film achieves this by hinting at the complex levels of meaning inherent in the image of a chimney, in Helmuth Joel's incredulous smile when he is talking of the letters spelling out his name, still visible in the bomb-site rubble of Nuremberg and in the pathos of the music - levels which the film successfully manages to link together.

That Die Akte foel and Mariannes Heimkehr do not present nostalgic memories despite connecting objects with emotions can be explained not least by the choice of core themes in these films. It is not only the case that the long-winded nature of the Aryanisation and restitution processes make emotional narration difficult, it is also true that the kinds of objects aryanisation deals with are less suitable for emotional attachments. Things of monetary value such as companies, real property and objects of utility were aryanised - that is objects whose emotional pull is, as a rule, much less strong than that of more personal items.

That personal items can have an enormous emotional effect becomes obvious, for instance, in the documentary film Menachem \& Fred (Ofra Tevet and Ronit Kertsner, Germany/Israel 2008) which tells the story of two brothers who are sent to an orphanage by their parents after the parents had been deported to a camp. They survive the Holocaust in the orphanage. After the war, Fred emigrates to the USA and Menachem to Israel. A few letters their mother wrote to them while they were in the orphanage are the only material items their parents could leave them.

\footnotetext{
${ }^{34}$ Regarding how survivors speak about their traumatic experiences cf. Lawrence Langer, Holocaust Testimonies: The Ruins of Memory, New Haven 1993.

${ }^{35}$ Walter Benjamin, The Arcades Project, Cambridge 1999, p. 463.

${ }^{36}$ Ibid., p. 473.
} 
By employing certain techniques the film imbues these letters with a special aura: when Menachem, for instance, is shown in close-up as he opens the leather folder containing the letters; slowly undoing its ties; opening it with both hands; and finally unfolding a letter written on paper which has become fragile with age, it is clear that the film means to emphasise the tactile quality of these letters.

The soundtrack provides whispered fragments of what these letters contain, suggesting the ghost-like presence of their mother who "after the fashion of a fingerprint ${ }^{\prime 37}$ has left her individual trace on the letters. The letters, thus charged with intense feelings, trigger an extreme emotional response as becomes evident, for instance, when Fred, who together with his brother has been visiting places connected to their childhood, is seen to shed tears when reading his mother's letters while sitting in his old room at the orphanage.

The emotional undertone in Menachem \& Fred, which is already obvious in the first minute when Fred bursts into tears when he remembers getting together again with Menachem for the first time, is closely connected to the themes addressed by this film. Considering the film's emphasis on emotions it is no coincidence that the film is not interested in finding out what happened to the household effects of the family after they had been deported to the Gurs camp. Menachem \& Fred chooses to focus on an emotional meeting of the two brothers with a former playmate, and a reconciliation with the children of the SA officer Emil Hopp. ${ }^{38}$ This kind of story leaves no room for critical enquiry about the (mis)appropriation of Jewish property by neighbours.

In contrast, Mariannes Heimkehr and Die Akte foel refrain from focusing on such personal matters. That the objects in these two films are emotionally charged to a lesser degree can also be explained by generational change. The children and grandchildren of the two families, by now firmly established in society, usually have a more distanced relationship with the aryanised objects in question than the Jewish businessmen and manufacturers who struggled to establish their businesses with their hard-earned money or who, as penniless Holocaust survivors, had to reclaim their household goods piece by piece. For Marianne's son the vase his mother had found in the possession of the village policeman seems to have meant as little as the factory in Berlin-Wedding meant to the grandchildren of KarlJoel. At least Die Akte foel seems to suggest this when it chooses to show Markus Neckermann visiting the empty factory buildings rather than Billy and Alexander Joel. But even Markus Neckermann surveys the building hardly showing any emotion, simply making a comment about the size of the property. The film thus suggests that the break in passing on (knowledge about) objects is an experience that does not only apply to families who have been deprived of their property by Aryanisation.

\footnotetext{
${ }^{37}$ Bazin, p. 15.

${ }^{38}$ Both Die Akte foel and Menachem $\&$ Fred benefit from the fact that the protagonists in these films are well-known personalties. Emil Hopp was the father of Dietmar Hopp, co-founder of the software company SAP and by now one of the richest men in Germany, very well-known, among other things, for his support of the professional football club 1899 Hoffenheim.
} 


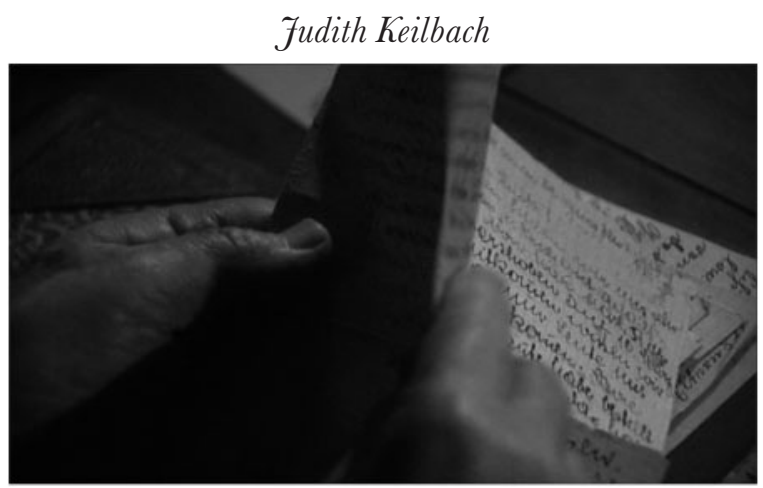

The letters from Menachem's mother to him, by courtesy of Menachem \& Fred (Ofra Tevet \& Ronit Kertsner, Germany/Israel 2008).

\section{Conclusion}

Both Die Akte foel and Mariannes Heimkehr are films dealing with the Aryanisation and restitution of Jewish property, using relatively conventional documentary means to do so. With the help of exemplary family histories the processes involved in Aryanisation are being traced while interviews with contemporary witnesses and historical footage are used to reconstruct the past. By using a twin-track approach of telling their stories, these two films are able to focus not only on the experiences of the expropriated and disenfranchised families but also on the topic of the extent to which the German neighbours and business partners took part in Aryanisation procedures and how they profited, and still profit to this day, from Aryanisation.

It is interesting to note that Die Aktefoel as well as Mariannes Heimkehr refrain from presenting original objects. Since both films are made in a rather conventional way, it is unlikely that such restraint is a reflexive strategy to portray loss. The comparison with other films, such as Menschliches Versagen und Menachem Ë Fred, shows that, if the aim is to portray loss, objects are often staged as being imbued with memories, thereby acquiring an auratic charge. While in these films the object-ness of such objects and their sensuous qualities are accentuated, Die Akte foel and Mariannes Heimkehr manage, by refraining from focusing on nostalgic memories, to emphasise the structural and institutional processes of Aryanisation and restitution all the more.

Considering how these films deal with objects one might suggest, in conclusion, that Mariannes Heimkehr and Die Akte foel are not only concerned with the loss of property but also with completely different topics the visualisation of which proves to be more difficult than that of the abstract concepts of Aryanisation and restitution. Both films also revolve around topics such as the loss of home, the need to bring the injustice that has been committed to public awareness, and the unhappiness that results from having been cheated out of a carefree, unburdened life - topics to which there are no easy answers even if there is a conciliatory ending. 